\title{
PENGETAHUAN DAN TINDAKAN PERSONAL HYGIENE SAAT MENSTRUASI PADA REMAJA
}

\author{
Ni Luh Agustini Purnama* \\ *STIKesKatolik St.Vincentius a Paulo Surabaya, Jl. Jambi 12-18 Surabaya. \\ e-mail: niluh.purnama20@ gmail.com
}

\begin{abstract}
ABSTRAK
Perawatan saat menstruasi perlu dilakukan karea jika kurang dijaga kebersihannya akan berpotensi terhadap timbulnya infeksi pada organ reproduksi. Dalam meningkatkan kebersihan organ reproduksi dan pencegahan penyakit, diharapkan untuk wanita memiliki pengetahuan yang baik sehingga dapat berpengaruh pada kebiasaan positif. Tujuan dari penelitian ini adalah mengidentifikasi hubungan antara tingkat pengetahuan dengan tindakan personal hygiene menstruasi remaja putri. Desain penelitian menggunakan cross sectional. Responden sebanyak 42 remaja putri di SMKN 4 Negara yang diambil dengan teknik simple random sampling. Pengetahuan dan praktik diukur dengan menggunakan kuesioner. Uji statistik yang digunakan dalam penelitian ini dengan uji Spearman. Dari dari 35 reponden yang berpengetahuan baik sebanyak $55(94,3 \%)$ tindakan personal hygiene saat menstruasinya dalam kategori baik. Hanya 1 responden yang memiliki pengetahuan ketegori kurang dengan tindakan personal hygiene yang tidak baik . Hasil Uji Rank Spearman menunjukkan nilai p< 0,05 artinya ada hubungan pengetahuan dengan tindakan personal hygiene saat mentruasinya. Nilai korelasi rho yaitu 0,47 hal ini arah hubungan positif dan kekuatan hubungan sedang. Arah hubungan positif artinya semakin tinggi skor pengetahuan maka semakin baik tindakan personal hygiene.
\end{abstract}

Kata kunci: Pengetahuan, Tindakan, Personal Hygiene, Remaja.

\section{ABSTRACT}

Treatment during menstruation needs to be done because if it is not kept clean, it will potentially lead to infection in the reproductive organs. In improving the hygiene of reproductive organs and preventing disease, it is hoped that women will have good knowledge so that they can influence positive habits. The purpose of this study was to identify the relationship between the level of knowledge and personal hygiene measures for female adolescents. The research design used cross-sectional. Respondents were 42 adolescents at SMKN 4 Negara who were taken using a simple random sampling technique. Knowledge and behavior were measured using a questionnaire. The statistical test used in this study was the Spearman test. The results showed that out of 35 adolescents with good knowledge, $55(94.3 \%)$ personal hygiene $m$ behavior during menstruation were in a good category. Only 1 adolescent had poor category knowledge with bad personal hygiene behavior during menstruation. The results of the Spearman Rank test showed that p-value $<0.05$, meaning that there was a relationship between knowledge and personal hygiene behavior in adolescents during menstruation. The rho correlation value is 0.47 , this is the direction of the positive relationship and the strength of the relationship is moderate. The direction of the positive relationship means that the higher the knowledge score, the better the personal hygiene behavior There is a relationship between knowledge and personal hygiene behavior hygiene behavior in adolescents during menstruation.

Keywords : Knowledge, Behavior, Personal Hygiene, Adolescents. 


\section{PENDAHULUAN}

Hygiene saat menstruasi merupakan hal penting dalam menentukan kesehatan organ reproduksi remaja putri . Personal hygiene menstruasi adalah peningkatan kesehatan melalui implementasi tindakan hygiene yang dapat dilakukan saat menstruasi dengan tujuan untuk pemeliharaan kebersihan dan kesehatan individu sehingga mendapatkan kesejahteraan fisik dan psikis serta dapat meningkatkan derajat kesejahteraan (Rosyida, 2019). Perawatan saat menstruasi perlu dilakukan hal ini dilatarbelakangi oleh peristiwa menstruasi yang merupakan darah kotor disertai rasa gatal dibagian vulva sehingga jika kurang dijaga kebersihannya akan berpotensi terhadap timbulnya infeksi pada organ reproduksi (Dita, 2010). Alat reproduksi dapat terkena sejenis jamur atau kutu yang dapat menyebabkan rasa gatal atau tidak nyaman apabila tidak dirawat kebersihannya (Kusmiran, 2014).

Pencegahan penyakit pada saluran reproduksi dapat diatasi apabila wanita giat menjaga kebersihan organ reproduksinya sehingga kuman tidak mudah masuk dan menimbulkan infeksi (Rosyida, 2019). Dalam meningkatkan kebersihan organ reproduksi dan pencegahan penyakit, diharapkan untuk wanita memiliki pengetahuan yang baik sehingga dapat berpengaruh pada kebiasaan positif sebagaimana yang diungkapkan menurut (Notoatmodjo, 2011) bahwa tindakan atau perilaku yang didasari dengan pengetahuan akan bersifat lebih lama (long lasting) dibandingkan dengan tindakan yang tidak didasari oleh pengetahuan. Masalah yang biasanya terjadi menurut Isro'in \& SulisAndarmoyo (2012) adalah kurangnya perilaku positif remaja putri untuk menjaga kebersihan organ reproduksi karena pengetahuan yang terbatas dan kurangnya minat belajar tentang kesehatan reproduksi.

Berdasarkan data Depkes RI (2014) di Indonesia prevalensi terjadinya infeksi saluran reproduksi akibat kurangnya hygiene pada organ genetalia adalah 90-100 kasus per 100.000 penduduk per tahun (Suryani, 2019) . Di provinsi Jawa Timur dan Bali sebanyak $77,3 \%$ remaja mempunyai pengetahuan yang kurang dalam hal kesehatan reproduksi (Badan Penelitian dan Pengembangan Kementerian Kesehatan RI, 2018), sedangkan data Dinas Kesehatan Surabaya (2019) terkait dengan perilaku remaja hanya $20,3 \%$ yang mengetahui informasi dan konsultasi tentang kesehatan reproduksi remaja.

Perilaku seseorang dipengaruhi oleh tingkat pendidikan dan pengetahuan dan dari pengetahuan seseorang tentang sesuatu tersebut dapat berpengaruh pada perubahan perilakunya (Notoatmodjo, 2011) hal ini sama menurut (Isro'in et al., 2012) bahwa pengetahuan seseorang tentang hygiene yang buruk akan sangat berdampak pada praktik hygiene. Menurut (Kusmiran, 2014) kurangnya tindakan dalam menjaga kebersihan genetalia seperti tidak mencuci tangan sebelum membuka dan memasang pembalut, malas mengganti pembalut dan pemakaian pembalut lebih dari 6 jam, membilas vagina dengan air kotor, penggunaan pembilas vagina yang berlebihan, pemeriksaan vagina yang tidak higienis, dan adanya benda asing dalam vagina dapat menyebabkan keputihan yang abnormal dan wanita rentan terkena penyakityaitu terjangkitnya infeksi jamur dan bakteri pada saat menstruasi. Menurut (Dita, 2010) (Dita, 2010) dampak pemakaian pembalut kadaluarsa dan penyimpanan pembalut di tempat yang lembab berakibat timbulnya bakteri sehingga dapat terjadi infeksi vagina dan jamur, selain itu malas mengganti pembalut atau pemakaian pembalut lebih dari 6 jam juga berpotensi menjadi wada dan sarana perkembangbiakan kuman dan bakteri yang merugikan yaitu masuknya kuman kedalam tubuh melalui vagina, lalu merembet keatas melewati mulut rahim yang menyebabkan peradangan, perekatan, lalu menyumbat saluran telur yang mengakibatkan kemandulan. Frekuensi pergantian pembalut yang terlalu lama juga akan 
menjadi sumber penyakit dan dapat menyebabkan gatal-gatal di daerah kemaluan, kemudian jika digaruk akan menyebabkan lecet, dan bisa terjadi infeksi (Haryono, 2016).

Petugas kesehatan perlu melakukan penilaian terkati pengetahuan dan praktik personal hygiene pada remaja sehingga bisa dilakukan intervensi yang tepat.. Dalam meningkatkan pengetahuan hygiene menstruasi dengan memberikan informasi kesehatan reproduksi sebagai upaya dalam meningkatkan program layanan kesehatan oleh para petugas kesehatan bekerjasama dengan para guru di sekolah, peran penting orang tua dalam mendampingi siswi, dan pengaruh teman sebaya dalam memberikan informasi (Haryono, 2016). Penelitian ini bertujuan mengidentifikasi hubungan antara tingkat pengetahuan dengan tindakan personal hygiene menstruasi remaja putri

\section{BAHAN DAN METODE}

Penelitian ini adalah penelitian observasi (non eksperimental) dengan rancangan penelitian cross sectional. Populasi dalam penelitian adalah remaja putri kelas XI jurusan Keperawatan di SMKN 4 Negara Kabupaten Jembrana Bali dengan kriteria inklusi: sudah menarch, bersedia menjadi responden. Jumlah sampel sebanyak 42 siswi melalui tehnik simple random sampling

Instrumen yang digunakan untuk mengukur pengatahun maupun tindakan personal hygiene menstruasi adalah kuesioner. Kuesioner untuk tingkat pengetahuan terdiri dari 13 pertanyaan dengan pilihan jawaban tertutup dimana masing masing pertanyan terdiri dari 3 pilihan jawaban. Uji validitas untuk kuesioner pengetahuan dengan 13 pertanyaan menunjukkan nilai didapatkan hasil valid dengan rentang nilai 0,361 0,444. Uji reabilitas untuk kuesioner pengetahuan menunjukkan nilai yang reliabel yaitu didapatkan hasil Alpha Cronbach 0,929. Tindakan atau praktik dinilai menggunakan kuesioner dengan metode recall dimana dilakukan dengan cara responden diminta untuk mengingat kembali perilaku atau tindakan yang telah dilakukan yang terdiri dari 10 pertanyaan. Pengumpulan data secara online menggunakan google form pada bulan November 2020.

Semua proses analisis data menggunakan paket program computer. Analisis univariat dilakukan pada masing-masing variabel untuk mengetahui distribusi frekuensi dan gambaran dari setiap variabel yang diteliti yaitu pengetahuan dan tindakan tindakan remaja putri terhadap personal hygiene saat menstruasi serta data demografi. Analisisi bivariat dilakukan untuk mengatahui hubungan antara pengetahuan dan tindakan remaja putri terhadap personal hygiene saat menstruasi. Uji statistik yang digunakan dalam penelitian ini dengan uji korelasi Spearman apabila data tidak berdistribusi normal. Pengolahan dan analisis data menggunakan program computer Pengolahan data statistik dengan tingkat kemaknaan $\mathrm{p}<0,05$ dan interval kepercayaan $95 \%$.

\section{HASIL}

Tabel 1 Karakteristik Responden

\begin{tabular}{lccc}
\hline \multicolumn{1}{c}{ Variabel } & $\begin{array}{c}\text { Frekuensi } \\
(\mathrm{n})\end{array}$ & $\begin{array}{c}\text { Presentase } \\
(\%)\end{array}$ & $\begin{array}{c}\text { Mean } \pm \\
\text { SD }\end{array}$ \\
\hline Usia (tahun) & & & $17,38 \pm 0,49$ \\
Informasi & & & \\
Pernah & 33 & 78,6 & \\
Tidak pernah & 9 & 21,4 & \\
Perubahan & & & \\
Fisik & & & \\
Senang & 42 & 97,6 & \\
Tidak senang & 1 & 2,4 & \\
\hline
\end{tabular}

Berdasarkan hasil penelitian rata-rata usia remaja adalah 17,38 tahun. Bila ditinjau dari pernah tidaknya responden mendapat infomasi maka sebagian besar $(78,6 \%)$ pernah mendapatkan informasi tentang personal hygiene saat menstruasi. Mayoritas responden $(97,6 \%)$ responden merasa senang dengan perubahan fisik yang terjadi selama masa remaja. Semua 
responden (100\%) pernah mendengar istilah personal hyigiene.

Tabel 2 Hasil Analisis Hubungan Personal Hubungan Tingkat Pengetahuan Dengan Tindakan Personal Hygiene Saat Menstrusasi Remaja.

\begin{tabular}{llll}
\hline & \multicolumn{3}{c}{ Tindakan } \\
& $\begin{array}{l}\text { Baik } \\
(\mathrm{n}=38)\end{array}$ & $\begin{array}{l}\text { Tidak Baik } \\
(\mathrm{n}-4)\end{array}$ & Nilai $\mathrm{p}$ \\
\hline Pengetahuan & & & \\
Baik $(\mathrm{n}=35)$ & $33(94,3 \%)$ & $2(5,7 \%)$ & $0,002 *$ \\
Cukup (n=6) & $5(83,3 \%)$ & $1(16,7 \%)$ & \\
Kurang $(\mathrm{n}=1)$ & $1(100 \%)$ & 0 & \\
\hline
\end{tabular}

signifikan $\mathrm{p}<0.05^{*}$

Berdasarkan tabel 2 dapat diketahui bahwa dari dari 35 reponden yang berpengetahuan baik sebanyak 55 (94,3\%) tindakan personal hygiene saat menstruasinya dalam kategori baik. Hanya 1 responden yang memiliki pengetahuan ketegori kurang dengan tindakan personal hygiene yang tidak baik . Hasil Uji Rank Spearman menunjukkan nilai $\mathrm{p}<0,05$ artinya ada hubungan pengetahuan dengan tindakan personal hygiene saat mentruasinya. Nilai korelasi rho yaitu 0,47 hal ini arah hubungan positif dan kekuatan hubungan sedang. Arah hubungan positif artinya semakin tinggi skor pengetahuan maka semakin baik tindakan personal hygienenya.

\section{PEMBAHASAN}

Budiman \& Riyanto (2013) menyebutkan bahwa informasi yang diperoleh baik dari pendidikan formal maupun non formal dapat memberikan pengaruh jangka pendek (immediate impact) sehingga menghasilkan perubahan atau peningkatan pengetahuan. Berdasarkan hasil penelitian, sebagian besar remaja memiliki pengetahuan baik. Bila ditinjau dari pernah tidaknya mendapatkan informasi maka sebagian besar pernah mendapatkan informasi, sumber inforasi juga bervariasi tenaga kesehatan ataupun media social. Hasil temuan ini juga didukung dengan penelitian yang dilakukan Pangaebean (2017) bahwa pemberian informasi melalui pendidikan kesehatan meningkatkan pengetahuan remaja putri tentang personal hygiene saat menstruasi.

Berdasarkan hasil penelitian mayoritas siswi memiliki tindakan personal hygiene saat menstruasi yang baik. Para siswa adalah jurusan keperawatan dimana pada kelas XI sudah mendapatkan pelajaran tentang kebersihan diri walaupuan tidak spesifik pada personal hygiene saat menstruasi. Hasil penelitian ini sejalan dengan penelitian yang dilakukan Suryani (2019) bahwa pemberian informasi berpengaruh terhadap perilaku personal hygiene saat menstruasi. dengan mendapatkan infirmasi melalui guru pada saat pelajaran sekolah maka para siswa mempraktikkannya ada kehidupan seharihari. Priyoto (2014) mengungkpakan bahwa salah satu faktor pendorong yang terwujud perilaku kesehatan melalui referensi dari perilaku masyarakat. Referensi tersebut dapat berupa dari guru.

Pengetahuan atau kognitif merupakan domain yang sangat penting untuk terbentuknya tindakan seseorang (overt behavior). Berdasarkan pengalaman dan penelitian tindakan yang didasarkan oleh pengetahuan akan bersifat lebih lama (long lasting) dibandingkan dengan tindakan yang tidak didasari oleh pengetahuan (Notoadmodjo, 2011). Hasil penelitian ini menunjukkan ada hubungan pengetahuan dengan tindakan personal hygiene saat mentruasinya, dengan arah hubungan positif dan kekuatan hubungan sedang artinya semakin tinggi skor pengetahuan maka semakin baik tindakan personal hygiene. Hasil ini sejalan dengan penelitian yang dilakukan Michael et al., (2020) bahwa ada hubungan antara pengetahuan remaja putri tentang menarch dan menstruasi dengan praktik personal hygiene menstruasi mereka remaja.

Hasil penelitian menunjukkan bahwa remaja putri yang memiliki pendidikan yang baik tentang menstruasi maka 
kebersihan hygiene personal menstruasi juga baik, pengetahuan remaja yang kurang maka praktik hygiene menstruasi juga tidak baik. Dalam penelitian yang dilakukan oleh Pemiliana et al., (2019); Zahara (2014). juga menunjukan bahwa remaja putri yang berpengetahuan kurang, tidak melakukan personal hygiene saat menstruasi. Hal ini sama dengan penelitian yang dilakukan oleh Astuti et al., (2016) yang menunjukan pengetahuan remaja putri tentang personal hygiene dengan kriteria kurang memiliki perilaku personal hygiene organ reproduksi dengan kriteria kurang

\section{KESIMPULAN DAN SARAN}

Berdasarkan hasil penelitian maka dapat disimpulkan mayoritas remaja memilik pengetahun baik tentang personal hygiene saat menstruasi. mayoritas remaja memiliki tindakan personal hygiene saat mentruasi yang baik. Ada hubungan pengetahuan dengan tindakan personal hygiene saat mentruasinya, dengan arah hubungan positif dan kekuatan hubungan sedang artinya semakin tinggi skor pengetahuan maka semakin baik tindakan personal hygienenya.

Pemberian informasi yang diberikan oleh guru SMKN 4 Negara atau melalui kegiatan UKS tetap dilakukan dan ditinggkatakan khususnya bagi rejama putri sehingga dapat meningkatakan pengetahuan remaja tentang personal hygiene saat menstruasinya, dengan pengetahuan yang baik maka tindakan personal hygiene juga akan baik.

\section{DAFTAR PUSTAKA}

Astuti, L. P., Dewi, N. S., \& Widiastuti, Y. P. (2016). Hubungan tingkat pengetahuan remaja putri dengan perilaku, 34-37.

Badan Penelitian dan Pengembangan Kementerian Kesehatan RI. (2018). Laporan Nasional Riskesdas 2018. Jakarta: Kementerian Kesehatan RI. https://doi.org/10.1017/CBO9781107
415324.004

Budiman \& Riyanto, A., \& Budiman, A. R. (2013). Kapita Selekta Kuesioner Pengetahuan dan Sikap dalam Penelitian Kesehatan. Jakarta: Salemba Medika.

Dita, A. (2010). Seluk Beluk Kesehatan Reproduksi Wanita. Yogyakarta: A. Plus Books.

Haryono, R. (2016). Siap Menghadapi Menstruasi Dan Menopause. Yogyakarta: Gosyen Publishing.

Isro'in, L., SulisAndarmoyo, S., \& Andarmoyo, S. (2012). Personal Hygiene konsep,proses dan aplikasi dalam praktik keperawatann. Yogyakarta: Graha Ilmu.

Kusmiran, E. (2014). Kesehatan reproduksi remaja dan wanita. Jakarta: Salemba Medika.

Michael, J., Iqbal, Q., Haider, S., Khalid, A., Haque, N., Ishaq, R., \& Saleem, F. (2020). Knowledge and practice of adolescent females about menstruation and menstruation hygiene visiting a public healthcare institute of Quetta , Pakistan. BMC Women's Health, 20(4), 1-8.

Notoatmodjo. (2011). Kesehatan Masyarakat Ilmu \& Seni. Jakarta: Rineka Cipta.

Pemiliana, P. D., Agustina, W., \& Verayanti, D. (2019). Perilaku Remaja Putri Dengan Personal Hygiene Saat Menstruasi di SMA Etidlandia Medan, 17(1).

Priyoto. (2014). Teori Sikap dan Perilaku Dalam Kesehatan. Yogyakarta: Nuha Medika.

Rosyida, D. A. C. (2019). Buku Ajar Kesehatan Reproduksi Remaja dan Wanita. Yogyakarta: PT Pustaka Baru. Suryani, L. (2019). Fakor-faktor Yang Mempengaruhi Perilaku Remaja Putri Tentang Personal Hgiene Pada Saat Menstruasi Di SMP Negeri 12 Kota Pekanbaru. Journal of Midwifery Science), 3(2), 68-79. Retrieved from L Suryani - JOMIS (Journal of Midwifery Science), 2019 - 
jurnal.univrab.ac.id

Zahara, C. R. (2014). Hubungan Penyuluhan Tentang Personal Hygiene dengan Perilaku Remaja Putri Pada Saat Menstruasi di SMU Cut Nyak Dhien Langsa. Universitas Sumatera Utara. 